\title{
THE CHANGES OF FOREST AREA IN KLAIPEDA COUNTY DURING THE PERIOD BETWEEN 2005-2019
}

\author{
Ivaviciute Giedre ${ }^{1 ; 2 ; 3}$ \\ ${ }^{1}$ Vytautas Magnus University, ${ }^{2}$ Kaunas Forestry and Environmental Engineering University \\ of Applied Sciences, ${ }^{3}$ Klaipeda State University of Applied Sciences
}

\begin{abstract}
The article presents the analysis of the current situation of the forest area in Klaipeda county. Comparative, analytical as well as statistical and logical analysis methods were used for the investigation. The aim of the investigation is to carry out the analysis of the Klaipeda county's forest area during the period between the years 2005 and 2019.

The object of the investigation - forest area of Klaipeda county. Tasks of the investigation: 1 . To describe the status quo of forest in Klaipeda county. 2. To analyze and compare the forest area change in Klaipeda county during the period between the years 2005 and 2019.

The study found that forests prevailing in Klaipeda County are of 60-69 years old. It was determined that fire trees prevail in Klaipeda County (25.64 percent) and pine (24.03 percent).

The type of ownership prevailing Klaipeda County is the forests of state significance managed by forest enterprises, national parks and state reserves (51.26 percent).

In the County there are mostly Group IV or commercial forests (62.47 percent).

In Klaipeda County during the period between the years 2005 and 2019 the forest area increased by 8269.85 ha or 6.03 percent.
\end{abstract}

Key words: forest area, forest coverage, type of ownership, climate change

\section{Introduction}

Article relevance. Forests cover nearly a third of all land on Earth, providing vital organic infrastructure for some of the planet's densest, most diverse collections of life. They support countless species. Forests are important both in terms of environmental and socio-economic aspects. From an environmental point of view, forests carry out ecosystem storage functions: contributing to soil conservation, climate regulation, and biodiversity conservation.

Forests play an important role in carbon storage and climate regulation, as well as supporting biodiversity (Benefits..., 2019).

Humans clear millions of acres from natural forests every year, especially in the tropics, letting deforestation threaten some of Earth's most valuable ecosystems.

Forests are a major, requisite front of action in the global fight against catastrophic climate change thanks to their unparalleled capacity to absorb and store carbon. Forests capture carbon dioxide at a rate equivalent to about one-third the amount released annually by burning fossil fuels. Stopping deforestation and restoring damaged forests, therefore, could provide up to 30 percent of the climate solution (Da Silva et. al., 2018).

Forests represent the largest sink of terrestrial carbon and continued storage, forest growth and removals for long life-span products may help reduce greenhouse gases in the future (Coulston et. al., 2015).

The world's forests influence climate through physical, chemical, and biological processes that affect planetary energetics, the hydrologic cycle, and atmospheric composition (Bonan, 2008).

Changes in patterns of tree growth can have a huge impact on atmospheric cycles, biogeochemical cycles, climate change, and biodiversity (Mc Mahon et. al., 2010).

Changing forest cover is a key driver of local climate change worldwide, as it affects both albedo and evapotranspiration (Prevedello et. al., 2019).

Problem. Effects of climate warming on natural and human systems are becoming increasingly visible across the globe (Harvey, 2016). Forest die-off constitutes a large uncertainty in projections of climate impacts on terrestrial ecosystems, climate-ecosystem interactions, and carbon-cycle feedbacks. Current understanding of the physiological mechanisms mediating climate-induced forest mortality limits the ability to model or project these threshold events (Anderegg et. al., 2012). 
Global warming is a well-known natural phenomenon that needs to be controlled for environmental conservation (Khaine, Woo, 2015).

Anthropogenic climate change presents potential risks to forests and future challenges for forest managers. Responding to climate change, through both mitigation and adaptation, may represent a paradigm shift for forest managers and researchers (Keenan, 2015).

Forest management has high potential for mitigating climate change effects, but only with support of insightful policy initiatives that take account of potential climatic changes (Duinker, 1990).

The forest cover in Klaipeda County is 26.25 percent, i.e. lower than in the Republic of Lithuania (33.07 percent). The county's natural framework system includes areas that have lost their natural landscape structure, valuable natural elements and are unable to perform ecological compensation functions. In some sections of regional and regional migration corridors, the diversity of the natural environment is impoverished. Intensive urban development, agriculture and uncontrolled recreation cause the greatest damage to the condition of the natural framework. Taking into account the current situation, it is necessary to carry out the development of the forest area in Klaipeda County.

The object of the investigation - forest area of Klaipeda county.

The aim of the investigation - to carry out the analysis of the Klaipeda county forest area during the period between the years 2005 and 2019 and to submit proposals for the implementation of further development.

Tasks of the investigation:

1. To describe the status quo of forest in Klaipeda county.

2. To analyze and compare the forest area change in Klaipeda county during the period between the years 2005 and 2019.

3. To evaluate the possibilities of forest development in Klaipeda County.

\section{Methodology of research and materials}

Comparative, analytical as well as statistical and logical analysis methods were used for the investigation. The article analyses works of Lithuanian and foreign scientists, published in scientific publications.

The land fund statistics of the Republic of Lithuania (Nacionaline zemes..., 2005-2019), graphically depicted in figures, were used for the fulfilment of the research of the forest area change in Klaipeda countyfor the years $2005-2019$.

The article analyzed and assessed the current state of the forest in the Klaipeda county, i.e. the prevailing tree species and age were determined, the distribution of forests by groups and ownership type was investigated.

The study provides the forest area change analysis in Klaipeda County. The 14 year period, i.e. the period between the years 2005 and 2019, was selected for the determination of the change. Statistics data were systematized, analyzed and expression of the percentage was calculated during the preparation of the research.

\section{Discussion and results}

The status quo of forest in Klaipeda county. According to the data of 2019, forests occupy 2158949.68 hectares in the Republic of Lithuania, and the country's forest is 33.07 percent. After analysing the current state of the forests in the Republic of Lithuania, it has been established that the most forested are Alytus (48.28 percent), Vilnius (42.91 percent), Telšiai (35.83 percent), Utena (34.88 percent), and Taurage (33.06 percent).

Klaipeda County is one of ten counties in Lithuania. It lies in the west of the country and is the only county to have a coastline. County occupied the area of 522245.08 ha, i.e. 8 percent of the entire area of the Republic of Lithuania. There are 7 municipalities: Klaipeda City, Klaipeda District, Kretinga District, Neringa, Palanga City, Skuodas District and Silute District.

In the Klaipeda County forests in 2019 occupied the area of 137089.62 ha, i.e. 26.25 percent of the entire area of the county. The largest part of Klaipeda County forests is made up by forests growing in the municipality of Silute district, which in 2019 occupied 37651.49 ha. The smallest forest area was established in Klaipeda city municipality (2023.64 ha).

It has been established that the most forested municipalities are Neringa (51.02 percent), Palanga City (39.21 percent) and Kretinga District (34.50 percent) (Fig.1). In the mentioned counties, the forest coverage is higher than the average of the Republic of Lithuania (33.07 percent).

Age of trees. The largest part of the growing forests consists of forests 60-69 years old, they make up 
13.06 percent, 50-59 years old forests make up 12.87 percent, $40-49$ years old -11.48 percent. $90-99$ years old forest make up 3.88 percent.

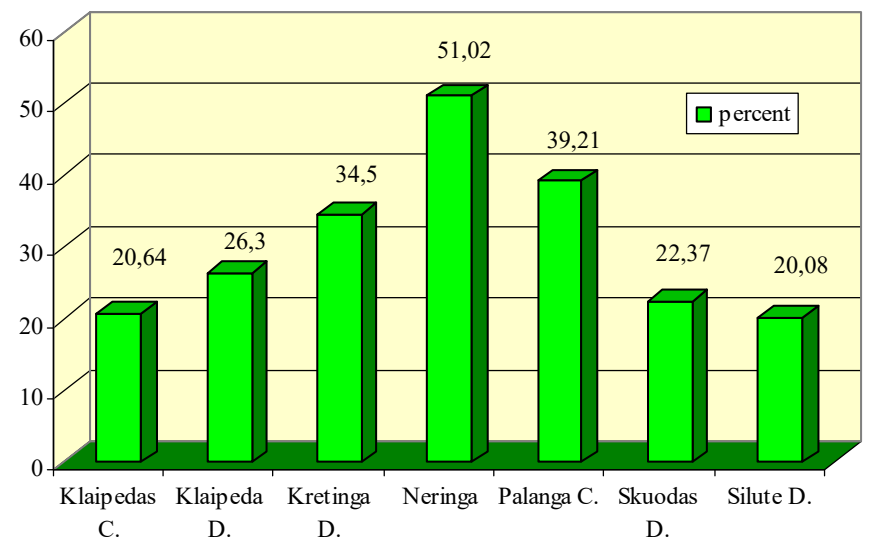

Fig. 1. Forest coverage in municipalities (percent) in 2019

(Consisted by the author of the article)

The prevailing tree species in the forest landscape are fir trees, which form 25.64 percent, as well as pine (24.03 percent) and birch trees (21.02 percent).

Coniferous species (56.20 percent) prevail in Lithuania forests, of which pine forests are dominant.

Distribution of forests in Klaipeda County by forest groups. In the County there are mostly Group IV or commercial forests (62.47 percent). Group II special-purpose forests make up 23.34 percent, Group III protective forests -12.24 percent.

In all of Lithuania's counties there are mostly Group IV commercial forests. These forests make up 71.40 percent, where the main purpose of farming is to form productive stands, to continuously supply wood. The least are Group I forest reserves (1.20 percent) (Ivaviciute, 2018).

According to the type of ownership, the forests are divided into the following: forests of state importance owned by forest enterprises, national parks and state reserves make up 51.26 percent, private and other forests -46.53 percent, state forests belonging to the Ministry of National Defense and the Ministry of the Interior - 0.47 percent. The municipal forests of state significance make up 0.46 percent, forests of state importance managed by the Ministry of Transport and Communications make up 0.10 percent, forests of state significance proposed to be excluded from the areas belonging to the Ministry of the Interior make up 0.06 percent, forests managed by forest enterprises and proposed to be included into the areas belonging to the Ministry of the Interior make up 0.05 percent and etc.

Forest area change in Klaipeda County. During the period under review, forest areas increased in 4 Klaipeda County municipalities: in Klaipeda City the forest area has increased by 231.02 ha or 12.89 percent, in Klaipeda district - 2988.26 ha or 8.59 percent, in Silute district - 3601.28 or 9.56 percent, in Skuodas district - 2871.81 ha or 18.63 percent. Skuodas district municipality has the largest forest development in Klaipeda County.

In Kretinga district forests fell by 823.11 ha or 2.35 percent, in Neringa - 461.13 ha or 6.51 percent, Palanga City - 138.28 ha or 4.45 percent (Fig. 2).

In the Klaipeda County during the period between the years 2005 and 2019 the forest area increased by 8269.85 ha or 6.03 percent and in 2019 occupied 137089.62 ha or 26.25 percent (Fig. 3).

During the period between the years 2005-2019 the forest area of the Republic of Lithuania increased by 120903.13 ha or 5.60 percent.

The area has increased due to the implementation of the forest improvement program, the promotion of plantation forests, the promotion of self-help to forest regeneration, participation in the Rural Development Program, and EU payments for this.

Forest development. In Klaipeda County, intensive forests are classified as economic forests (forest group IV). Forestry activities shall promote efficient multi-purpose use of forests to ensure economic viability and a wide range of environmental and social functions. Economic activities in this group of forests shall aim at preserving biodiversity and related values, water resources, soil, unique and fragile ecosystems and landscapes, and maintaining the ecological functions of the forest and the integrity of forests. 


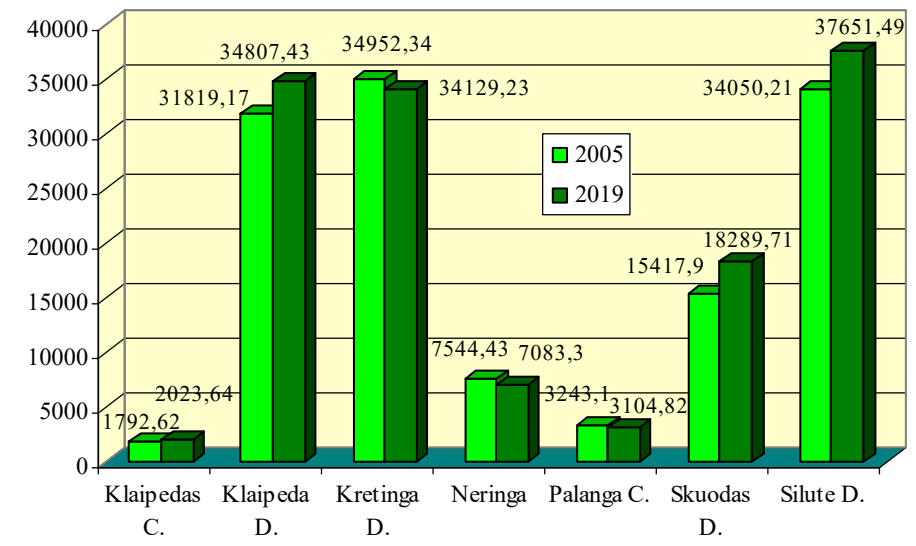

Fig. 2. Forest area change in Klaipeda County municipalities in ha during the years 2005-2019

(Consisted by the author of the article)

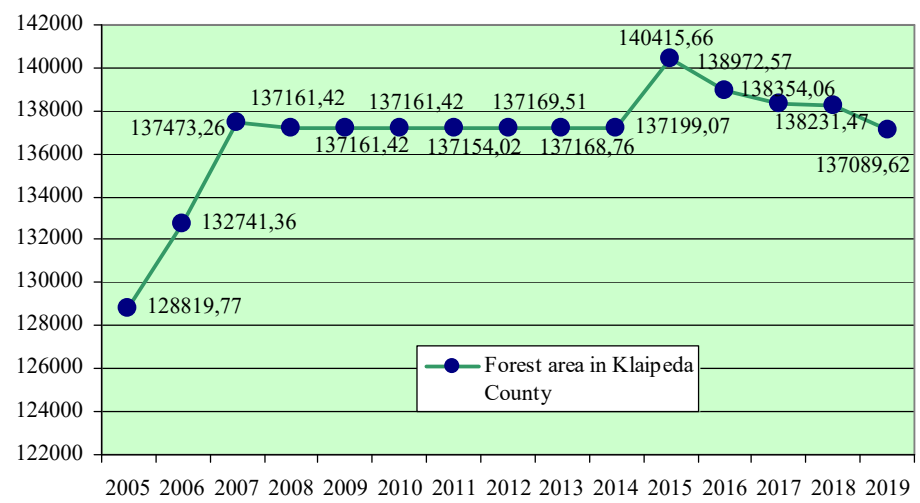

Fig. 3. Forest area change in Klaipeda County in ha during the years 2005-2019

(Consisted by the author of the article)

Sustainable farming zone includes ecosystem protection forests (forest group IIA) - protected forests, habitat and natural resource forests and anti-erosion forests; recreational forests (forest group IIB) include forest park forests and recreational forest areas; protected forests (forest group III) - forests in protected areas, field protective forests, nurseries of forest tree seedlings and forests of protected water bodies. Sustainable, multifunctional use of forests would contribute to the stability of forest ecosystems, the preservation of existing natural and cultural assets, the maintenance of biodiversity, as well as solution of economic issues.

According to the Resolution of the Government of the Republic of Lithuania "On Approval of the Master (General) Plan of the Territory of Klaipeda County " (Lietuvos ..., 2016), reforestation on nonproductive land shall be assigned to the zone or group of forests to which adjacent forests are assigned. It is recommended that primary forest planting be planned in pre-erosion forests, field protective forests, and forests of protected water bodies.

It is planned to develop forestry activities in Klaipeda County on forest land as well as in forests located on the land used for agricultural purposes. By increasing the overall forest cover rate of Klaipeda County, it is planned to afforest non-productive land. The afforestation of the territories of the county is planned to be carried out in accordance with the approved land management schemes for forest layout of the municipalities of Skuodas district, Kretinga district, Klaipeda district and Silute district. The forests designed in the schemes have been identified as priority areas where afforestation should be encouraged and their solutions can be implemented to the extent that they do not contradict the solutions of the current Klaipeda County Master plans.

Although the forest area increased in the period of the year 2005-2019, the goals provided for in the Klaipeda County Master Plan were not achieved, i.e. to increase the forest cover in the county to 28.00 percent by 2020. In order to achieve this goal, it is necessary to afforest 9139.00 ha.

According to the data of the National Land Service under the Ministry of Agriculture, in Klaipeda County in 2019 there were 9615.02 ha of land not used for agriculture and unfit for use, of which 5239.86 ha were not used for agriculture and 2543.90 ha were damaged land and 1831.26 ha were 
abandoned land. Most of this land is state-owned. After afforestation of all this land, the forest cover of the county would increase by about 7.01 percent and occupy 146704.64 ha as well as will make up 28.09 percent of the county territory.

As almost all areas of Klaipeda, Silute and Kretinga districts are sensitive to wind erosion, poorly insulated depths prevail, therefore in these zones it is necessary to regulate the intensity of land use, increase the amount of greenery, increase the area of forestry land.

After the implementation of the Klaipeda County Master Plan solutions, the forest area will increase in the future. In assessing the relevance of increasing forest cover, the classic aspects of sustainable development - ecological quality, economic development and social development - must be taken into account. Thus, the increase of forest cover is determined by a complex of legal, socio-economic and ecological-environmental factors.

Forest is one of the most important landscape components of biodiversity, sustainable ecosystems and landscaping, so its rational use and protection is essential.

\section{Conclusions}

1. After examining the forests according to their age, it was obtained that forests prevailing in Klaipeda County are of 60-69 years old.

2. After analyzing the prevailing species of trees, it was determined that fire trees prevail in Klaipeda County (25.64 percent) and pine (24.03 percent) as well.

3. In Klaipeda County during the period between the years 2005 and 2019 the forest area increased by 8269.85 ha or 6.03 percent.

4. Forest areas increased in 4 municipalities: in Klaipeda City the forest area has increased by 231.02 ha or 12.89 percent, in Klaipeda district - 2988.26 ha or 8.59 percent, in Silute district - 3601.28 or 9.56 percent, in Skuodas district - 2871.81 ha or 18.63 percent.

5. In Kretinga district forests decreased by 823.11 ha or 2.35 percent, in Neringa by 461.13 ha or 6.51 percent, and in Palanga City - 138,28 ha or 4.45 percent.

6. After afforestation of land not used for agriculture and unsuitable for use (9615.02 ha), the forest cover of the county would increase by about 7.01 percent and occupy 146704.64 ha and make up 28.09 percent of the territory of Klaipeda County. It is recommended that forest planting be planned in pre-erosion forests, field protective forests, and forests of protected water bodies as well.

\section{References}

1. Anderegg W.R.L., Berry J.A., Smith D.D., Sperry J.S., Anderegg L.D.L, Field CH.B. (2012). The roles of hydraulic and corbon stress in a widespread climate-induced forest die-off. PNAS, 109 (1). P. 233237. (https://doi.org/10.1073/pnas.1107891109.

2. Benefits of trees. (2019). Nature Climate Change. 9, 569. doi:10.1038/s41558-019-0556-z.

3. Bonan G.B. (2008). Forest and climate change: forcing, feedbacks, and the climate benefits of forests. Science. volume 320. P. 1444-1449.

4. Coulston J.W., Wear D.N., Vose J.M. (2015). Complex forest dynamics indicate potential for slowing carbon accumulation in the southeastern United States. Scientific Reports. No. 5.

5. Da Silva J.G., Steiner A., Solheim E. (2018). Forests: A natural solution to climate change, crucial for sustainable future. UN environment programme. Viewed 03 December, 2019. (https://www.unenvironment.org/news-and-stories/story/forests-natural-solution-climate-change-crucialsustainable-future.

6. Duinker P.N. (1990). Climate change anf forest management, policy and land use. Land Use Policy. volume 7, Issue 2. P. 124-137.

7. Harvey B.J. (2016). Human-caused climate change is now a key driver of forest fire activity in the western United States. PNAS. 113 (42). P. 11649-11650. (https://doi.org/10.1073/pnas.1612926113.

8. Ivaviciute G. (2018). The Change of Forest and their Area in Lithuania // Research for rural development 2018: annual 24rd international scientific conference proceedings / Latvia University of Agriculture. Jelgava. ISSN 1691- 4031. 2008. $174-180 \mathrm{p}$.

9. Keenan R.J. (2015). Climate change impacts and adaptation in forest management: a review. Annals of Forest Science. Volume 72, Issue 2. P. 145-167.

10. Khaine I., Woo S.Y. (2015). An overview of interrelationship between climate change and forests. Forest Science and Technology. Volume 11, Issue 1. P. 11-18. (https://doi.org/10.1080/21580103.2014.932718.

11. Lietuvos Respublikos Vyriausybès nutarimas "Dèl Klaipèdos apskrities teritorijos bendrojo (generalinio) plano patvirtinimo" (Resolution of the Government of the Republic of Lithuania "On Approval of the Master Plan of the Territory of Klaipeda County"), (2016 07 20, Nr. 769) (TAR, 201607 27, Nr. 21059) (in Lithuanian). 
12. McMahon S.M., Parker G.G., Miller D.R. (2010). Evidence for a recent increase in forest growth. PNAS. 107 (8). P. 3611-3615. (https://doi.org/10.1073/pnas.0912376107.

13. Nacionalinè žemès tarnyba prie Žemès ūkio ministerijos. Lietuvos Respublikos žemès fondas. (National Land Service under the Ministry of Agriculture. Land Fund of the Republic of Lithuania). Vilnius, 20052019. - 144 p. (in Lithuanian).

14. Prevedello J.A., Winck G.R., Weber M.M., Nichols E., Sinervo B. (2019). Impacts of forestation and deforestation on local temperature across the globe. PLOS. https://doi.org/10.1371/journal.pone.0213368.

Information about authors:

GIEDRE IVAVICČIUTE, Lecturer, Institute of Land Use Planning and Geomatics, Water and Land Management faculty, Vytautas Magnus University. Address: Universiteto g. 10, LT - 53361 Akademija, Kauno raj., Lithuania. Tel. 8 - 377523 72, e-mail: ivavice@gmail.com . Fields of interest: landscape architecture, rural development.

Lecturer, Kaunas Forestry and Environmental Engineering University of Applied Sciences. Address: Liepų st. 1, Girionys, LT -53101, Kauno raj. Lithuania. e-mail: ivavice@gmail.com.

Lecturer, Klaipeda State University of Applied Sciences. Address: Jaunystès st. 1, LT-91274, Klaipėda, Lithuania. e-mail: ivavice@gmail.com. 